reserving its position on other proposals such as the need to reduce the concentration of lead in the working environment or in a third of Britain's drinking-water. An earlier government's hasty acceptance of the Robbins report on higher education may yet haunt the present Prime Minister, her heirs and her political assignees.

Both parties, the commission and the government, are in cleft sticks. The commission, fully aware that only practicable recommendations will carry weight and properly alarmed that many British residents have enough lead in their blood that overt toxicity is within sight, proposes that lead pollution should be reduced in the course of the next ten years or so by banning lead in petrol. The government, especially aware at this stage in its constitutional term of office that the toleration of pollution must invite electoral unpopularity (to say the least), accepts this drastic measure as a must, but specifically reserves its position on what might be equally valuable strategies such as an attempt to understand what happens in airborne dust (can it contain so much lead, can children consume so much but adults so little?). Neither the oil companies nor the motor-car manufacturers will suffer, for their extra costs will in due course be passed onto their customers, the car-driving lead-breathing tax-paying electors whose interests are meant to be safeguarded by the new policies.

The British Government's decision to embrace the commission's recommendation at the very hour of its publication would be more persuasive if the reasons for the peculiar accumulation of lead in the blood of children were better understood. Naturally, and properly, students of lead pollution have paid particular attention to the apparently rapid accumulation of lead in the bodies of people aged two or three, and to the possibility (even now unconfirmed, however) that their intelligence may as a consequence be impaired. To be truthful, the British commission's report on lead pollution, a model of how public documents should deal with technical subjects, is no more able than its predecessors on this subject to account for the accumulation of lead in young children. Like previous deliberative bodies, the commission supposes that the difference between young children and adults is that the former suck their fingers more assiduously, ingesting more leadbearing dust in the process. The problem of airborne dust deserves the attention the commission urges, but there is nothing in its report to prove that the relatively higher concentrations of lead in the blood of children are signs that children are more likely to be permanently damaged. It could be that they are more efficient at mobilizing lead from functional organs and of excreting it. None of this would argue against an attempt to reduce lead pollution, even by banning lead additives in petrol, but a measure of deliberation would be seemly.

Even now, two other courses of action than that adopted by the British Government would be wise. For most people in Britain, lead in diet (including piped water) is the chief source of lead contamination, with urban and industrial dust for many people a close second (and for some a first). Dietary lead is not easily controlled, but the lead composition of dust could be tackled within the framework of extant regulations (which, to its credit, the commission recommends). But especially if dust is the chief source of lead contamination in infancy, should not the battle against lead in dust deserve equal importance with that against lead in petrol? And should there not be more public money for research and development on internal combustion engines, not just for the sake of obviating the need for lead additives but in the hope of working an obviously emergent market?

For whatever the hazards of body-borne lead, there is no doubt that lead has now become permanently unpopular. The royal commission's case for reducing the general contamination by lead is strong, and cannot be gainsaid, but it has been shamefully and dishonestly exaggerated by the anti-lead lobby. The maddening but plain truth is that attempts to correlate childhood IQ with blood-lead concentration have so far failed (which is not to say that they should not have been made). Unfortunately, this seems not to have dissuaded the lobbyists from asserting that white - or rather, grey - is black. Now the British Government has uncharacteristically thought it prudent to listen to what the lobbyists have been saying.

\section{Another team player?} Against the odds, the US Senate has confirmed Kenneth Adelman as arms control director.

THERE can be no disguising the magnitude of President Reagan's personal victory last week in persuading the Senate to brush aside the recommendation of its own Foreign Relations Committee by confirming Kenneth L. Adelman as the new director of the Arms Control and Disarmament Agency (ACDA). The victory was unexpected and, with a vote of 57 to 42 , entirely convincing. Those who laboured long to block the nomination, notably Senators Alan Cranston of California and Paul Tsongas of Massachusetts, have been quick to describe the outcome as a setback for arms control that will delight the Soviet Union and confound NATO. They may just be wrong.

The original objections to Mr Adelman's nomination centred, correctly enough, on his personal qualities and experience - a test on which it would be hard for any 36-year-old to measure up to the standards set by Mr Eugene Rostow, whom President Reagan dismissed as director of the agency in January. $\mathrm{Mr}$ Adelman's cause was further muddied, during the prolonged con-

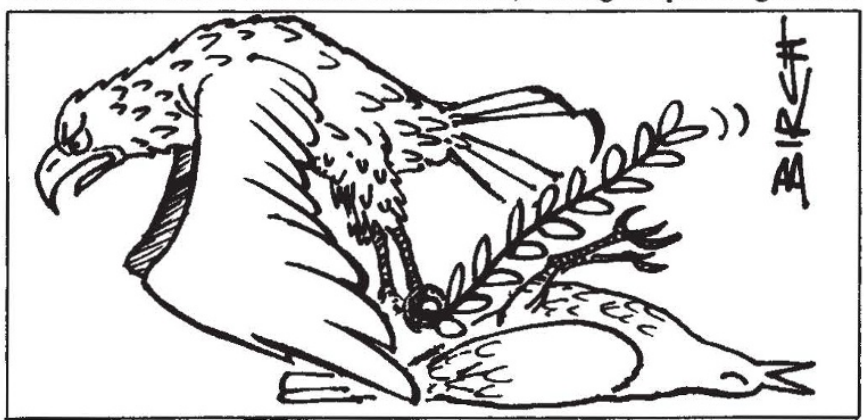

firmation hearings, by suggestions that he distrusted the whole notion of arms control and that he deliberately misled his inquisitors during questions about proposed personnel changes at ACDA. But these considerations, however weighty, later became subsumed in the larger question of whether the Reagan Administration itself is committed to a serious and achievable arms control policy.

There is of course no reason why the committee should not have raised this larger question. Its members were probably right to conclude that $\mathrm{Mr}$ Adelman lacked the stature and indeed the will to become anything other than the loyal instrument of an already flawed arms control philosophy. But there are at least two reasons for hope that, having finished its negotiations with the Senate, the administration will now be able to pursue a more productive strategy in its negotiations with the Soviet Union.

First, Mr Adelman's confirmation will at last lay to rest the misguided belief that a liberal figure should be placed at the head of ACDA regardless of the political complexion of the rest of the administration. The putative independence of the agency has been at best a sham, at worst a device for ensuring that the President and his chief arms control expert are at each other's throat. Whatever his defects, Mr Adelman has the merit of being in close agreement with President Reagan, Mr Shultz and Mr Weinberger, and therefore in a better position to formulate a policy which has the unanimous support of those who wield real power in the arms control arena.

Second, President Reagan has had to pay a considerable political price to secure last week's vote in the Senate. Eight Democrats and several liberal Republicans who were expected to oppose Mr Adelman's confirmation changed their minds after last-minute pleading from the White House. It is to be supposed that they did so only after extracting a number of firm promises that the President will move swiftly to prove to the doubters that the administration has a genuine interest in progress on arms control. By the same token, the appointment of Mr Adelman, a man trusted by the Senate hawks, may ease the administration's task when it tries to sell an arms control package to the likes of Senator Jesse Helms of North Carolina. 